\title{
The Restorative Justice Effectiveness In Law Enforcement of Damage Of Goods Crime
}

\author{
Vikha Anief Obaydhillah*) and Gunarto**) \\ *) Police of Grobogan, E-mail: vikha.AObay@gmail.com \\ ${ }^{* *}$ ) Faculty of Law Universitas Islam Sultan Agung
}

\begin{abstract}
Legal settlement based on restorative justice in the crime of destruction of goods is basically a more effective and efficient solution, however, not all people are willing to carry out this legal effort. This study aims to analyze more deeply the position of restorative justice in law enforcement in cases of destruction of goods. The research approach used is sociological juridical. The results of the analysis in this paper find the fact that the settlement of cases based on restorative justice which is carried out through legal remedies outside the court basically has advantages. The main advantage of resolving cases including criminal cases outside the court with alternative dispute resolution (ADR) is that decisions made by the parties themselves (win win solutions) reflect a sense of justice. However, this has not been effective in resolving cases of vandalism. This is shown by the data above which shows the lack of implementation of alternative dispute resolution in resolving criminal cases of vandalism in the community.

Keywords: Damage of Goods; Restorative Justice; Law Enforcement; Crime.
\end{abstract}

\section{Introduction}

Restorative justice is an alternative settlement of criminal cases which in the criminal justice procedure mechanism focuses on punishment which is converted into a dialogue and mediation process that involves the perpetrator, victim, family of the perpetrator/victim, and other related parties to jointly create an agreement on the settlement of a criminal case that is fair and balanced for both the victim and the perpetrator by prioritizing restoration to its original state and restoring the pattern of good relations in society. ${ }^{1}$

The purpose of holding this restorative justice is to reform the criminal justice system which still prioritizes prison criminal law. The development of the criminal system is no longer based on the perpetrator but has led to the alignment of the interests of the victim's recovery and the accountability of the perpetrators of criminal acts. ${ }^{2}$

The basic principle of restorative justice is the existence of restoration to victims who suffer as a result of crime by providing compensation to victims, peace, perpetrators doing social work or other agreements. A fair law in restorative justice is certainly not one-sided, impartial, not arbitrary, and only sided with the truth in accordance with applicable laws and regulations and considers equal rights to compensation and balance in every aspect of life.

\footnotetext{
${ }^{1}$ Abdul Wahid and Muhammad Irfan, Perlindungan Terhadap Korban Kekerasan Seksual, Refika Aditama, Bandung, 2001, p. 30.

${ }^{2}$ https://badilum.mahkamahagung.go.id/index.php?option=com attachments\&task=download\&id= $\underline{811}$ accessed on 17 April 2021.
} 
Perpetrators have the opportunity to be involved in restoring the situation (restoration), the community plays a role in preserving peace and the courts play a role in maintaining order. ${ }^{3}$

Criminal cases that can be resolved with restorative justice are cases of minor crimes with criminal threats as regulated in 364, 373, 379, 384, 407 and Article 482 of the Criminal Code with a loss value of not more than IDR 2,500,000, (two million five hundred rupiah), women's cases dealing with the law, children's cases and narcotics cases.

As the case study of this research, the crime of vandalism as regulated in Article 407 of the Criminal Code is a crime that can be resolved with restorative justice, which reads as follows:

Whoever intentionally and unlawfully destroys, damages, renders unusable or loses something which is wholly or partly owned by another person, shall be punished by a maximum imprisonment of two years and eight months or a maximum fine of four thousand five hundred rupiahs.

The purpose of destruction in criminal law is to act against other people's goods without taking the goods. Destruction of goods is very detrimental, whether the damaged goods are only partially or completely, so that the person cannot use the goods anymore. In addition, goods that have been damaged are something of value to someone, with the destruction of these goods, it is very disturbing the peace of society.

The Indonesian National Police (Polri) is a state instrument that plays a role in maintaining public security and order, law enforcement, protection, shelter, and service to the community in the context of maintaining domestic security. Therefore, the National Police are required to continue to develop to be more professional and closer to the community. ${ }^{4}$ In other words, the Police are required to develop themselves into civilian police. As a civilian police, the position of the National Police in state organizations has a dominant influence in the implementation of the police in a proportional and professional manner which is a prerequisite for supporting the realization of good governance. ${ }^{5}$

Thus, in handling criminal acts of vandalism, the National Police as a basic level law enforcement officer has the responsibility, in a professional way trying to reconcile the parties involved in the destruction by means of penal mediation, or better known as criminal mediation. That the settlement of minor criminal cases through restorative justice can be carried out provided that peace has begun to be carried out between the perpetrators, victims, families of perpetrators/victims, and related community leaders who are litigating with or without compensation. ${ }^{6}$

The main advantage of resolving cases (including criminal cases) out of court with alternative dispute resolution (ADR) is that decisions made by the parties themselves (win win solutions) reflect a sense of justice. Although in the

${ }^{3}$ https://badilum.mahkamahagung.go.id/index.php?option=com attachments\&task=download\&id= 811, accessed on 17 April 2021.

${ }^{4}$ Warsito Hadi Utomo, 2005, Hukum Kepolisian di Indonesia, Jakarta: Prestasi Pustaka, p. 536.

${ }^{5}$ Article 1 points 30, 31, 32, and 33 of Act No. 22 concerning Road Traffic and Transportation.

${ }^{6}$ Oscar Stefanus Setjo and dan Umar Ma'ruf, Investigation of Children Which Conflicting With Law in Narcotics Criminal Acts In Law Area of the Semarang City Police Jurisdiction, Jurnal Daulat Hukum Volume 3 Issue 2, June 2020, p. 287-288. 
examination of peace cases in general only civil cases, but in practice the settlement of criminal cases is also often resolved outside the court. Western society (America, England, Canada and Japan) the crisis that occurred in the judiciary has triggered the emergence of an alternative dispute resolution movement. ${ }^{7}$

The change in the investigative model from being purely punitive (punishing) to restorative (recovering perpetrators and victims) is a change that is more than just a technique, but a culture of investigation. Therefore, it requires a long process of adaptation, which seems to be irreversible. The involvement of the victim (victim's participation scheme) in the investigation or investigation process is not easy because it demands a change from the usual "closed" patterns to become more "open". The purpose of this paper is to identify and analyze the implementation of the restorative justice system in law enforcement in cases of destruction of goods.

\section{Research Methods}

The research approach used in this study is juridical sociological. The specification in this paper is descriptive analytical. Methods of collecting data by means of field studies and literature studies. Methods of data analysis using qualitative methods.

\section{Results and Discussion}

\subsection{Implementation of Restorative Justice in Cases of Damage of Goods}

The existence of out-of-court settlement of cases through restorative justice or penal mediation is a new dimension studied from the theoretical and practical aspects. Judging from the practical dimension, penal mediation will correlate with the achievements of the judiciary. As time goes by, there is an increasing number of cases in all forms and variations that go to court, so that the consequences become a burden on the judiciary, namely legal certainty, benefit and justice. ${ }^{8}$ Do all kinds of criminal cases have to be filed and settled in court, or are there certain cases that allow them to be resolved through a penal mediation pattern. ${ }^{9}$ In the case of polarization and penal mediation mechanisms, as long as this is seriously desired by the parties (suspects and victims), as well as to achieve wider interests, namely the maintenance of social harmonization. ${ }^{10}$

\footnotetext{
7Ibnu Suka, Gunarto, and Umar Ma'ruf, Peran Dan Tanggung Jawab Polri Sebagai Penegak Hukum Dalam Melaksanaan Restorative Justice Untuk Keadilan Dan Kemanfaatan Masyarakat, Jurnal Hukum Khaira Ummah Vol. 13. No. 1. March 2018, p. 115-116.

${ }^{8}$ Ragil Tri Wibowo and Akhmad Khisni, Restorative Justice in Application for Crime Investigation on Property, Jurnal Daulat Hukum Volume 1 No. 2 June 2018, p. 555-556.

${ }^{9}$ Malik AL-Ghazali, Restorative Justice Approach on The Under Age (Minors) Violator of The Traffic Case Accident (Laka) That Lead to Death in Majalengka Police, Jurnal Daulat Hukum Volume 1 Issue 3 September 2018, p. 708-800.

${ }^{10}$ Iman Faturrahman and Bambang Tri Bawono, Application of Restorative Justice to Solution of Traffic Accidents, Jurnal Daulat Hukum Volume 4 Issue 1, March 2021, p. 30-31.
} 
Meanwhile, the legal basis or legal umbrella for the National Police for the settlement of criminal cases outside the court of alternative dispute resolution by means of peace is as follows: 11

- Settlement of cases outside the court on the basis of law by way of peace, according to the laws and regulations, namely:

- Article 3 paragraph (1) of Act No. 14 of 1970 concerning Judicial Powers, State Gazette of 1970 Number 74 affirmed "all courts in the entire territory of the Republic of Indonesia are state courts and are stipulated by law. This article means that in addition to state courts, it is no longer allowed to have state courts conducted by non-state judicial bodies. Settlement of cases out of court on the basis of peace or through a referee (arbitration) is still allowed.

- Article 3 paragraph (1) of Act No. 4 of 2004 concerning Judicial Power, State Gazette of 2004 Number 8 which has been amended several times, most recently by Act No. 48 of 2009 concerning Judicial Power, all courts throughout the territory of the Republic of Indonesia is a state court and is determined by law; stated in the explanation: "This provision does not rule out the possibility of settlement of cases being carried out outside the State courts through reconciliation or arbitration;

- Article 3 paragraph (2) of Act No. 4 of 2004 concerning the Judicial Powers of the State Courts implements and affirms law and justice based on Pancasila.

- Article 7 paragraph (1) letter $\mathrm{j}$ of the Criminal Procedure Code in conjunction with Article 16 paragraph (1) letter i of Act No. 2 of 2002 concerning the Indonesian National Police for the process of criminal acts (investigations and investigations) has the authority to "carry out other actions according to the law that are responsible".

- Article 7 paragraph (1) letter $\mathrm{j}$ of the Criminal Procedure Code in conjunction with Article 16 paragraph (1) letter i of Act No. 2 of 2002 concerning the POLRI for criminal proceedings (investigations and investigations) has the authority to "take other actions according to the law that is responsible.

- Article 12 of PERKAP NO. 6 of 2019 concerning the investigation of criminal acts stipulates "In the process of investigating criminal acts, restorative justice can be carried out".

The main advantage of resolving cases (including criminal cases) out of court with alternative dispute resolution (ADR) is that decisions made by the parties themselves (win win solutions) reflect a sense of justice. ${ }^{12}$ Although the examination of peace cases is generally only a civil case, in practice the settlement of criminal cases is also often resolved outside the court. Western society

\footnotetext{
${ }^{11} \mathrm{M}$. Gargarin Friyandi and Aryani Witasari, Restorative Justice In Application For Crime Investigation of Abuse In Semarang Police, Journal of Legal Sovereignty Volume 2 Issue 1, March 2019, p. 41-44.

${ }^{12}$ Annis Nurwianti, Gunarto, Sri Endah Wahyuningsih, Implementasi Restoratif / Restorative Justice Dalam Penyelesaian Tindak Pidana Kecelakaan Lalu Lintas Yang Dilakukan Oleh Anak Di Polres Rembang, Jurnal Hukum Khaira Ummah Vol. 12. No. 4, p. 707-709.
} 
(America, England, Canada and Japan) the crisis that occurred in the judiciary has triggered the emergence of the alternative dispute resolution movement.

\subsection{The Effectiveness of the Justice Restorative System in Criminal Cases of Damage of Goods}

Restorative justice or restorative justice is the settlement of cases by involving the perpetrators, victims, or their families and other related parties to jointly seek a fair solution by emphasizing restoration to its original state, and not retaliation. In the Academic Manuscript of the Juvenile Justice System Bill, it is stated that criminal justice for children by taking a restorative approach has the following objectives: ${ }^{13}$

- seek peace between victims and children;

- prioritizing settlements outside the judicial process;

- keep children away from the negative influence of the judicial process;

- instill a sense of responsibility in children;

- realizing child welfare;

- prevent children from deprivation of liberty;

- encourage people to participate;

- improve children's life skills

The principles of restorative justice are related to the relationship between crimes and some of the basic principles of restorative justice related to the relationship between crime and the perpetrator, crime with the victim, crime with society and crime with the state. The explanation of the principles regarding restorative justice is as follows: ${ }^{14}$

- Crime is seen as a social act that is considered not only seen as a violation of the law.

- Restorative justice is considered a theory related to juvenile criminal justice which focuses on the view that crime is seen as a crime committed by a person to society, or an individual rather than a crime being seen as a crime committed by the perpetrator against the state.

- Crime has been considered and seen as an act that harms someone so that it causes damage to social relations. This problem is clearly different from criminal law which so far views crime as a problem that is detrimental to the state and must be resolved between perpetrators of criminal acts against the state, so that in the view of criminal law it is considered that only the state has the right to impose sanctions on perpetrators of criminal acts.

- With the emergence of the idea of restorative justice, it is a criticism of the implementation of the criminal justice system carried out by the state by carrying out punishment through imprisonment for criminal acts, and this

\footnotetext{
${ }^{13}$ Arif Septria Hendra Saputra, Gunarto, and Lathifah Hanim, The Application of Restorative Justice as an Alternative for the Settlement of the Crime of Persecution at the Lasem Police Satreskrim, Jurnal Daulat Hukum Vol. 1. No. March 1 2018, p. 159.

${ }^{14}$ Sarwadi and Bambang Tri Bawono, Restorative Justice Approach in Diversion System for Settlement of Criminal Cases for Children in Indonesia, Jurnal Daulat Hukum Volume 3 Issue 4, December 2020, p. 377-400.
} 
criticism assumes that the process of resolving cases through imprisonment is considered ineffective in resolving social conflicts that arise from these crimes. .

The research case of truck vandalism occurred in Ponorogo, East Java. Seven residents of Ponorogo, East Java, were arrested by the Wonogiri Police Resmob team after destroying an egg-carrying truck. The incident occurred in Biting Village, Purwantoro District, Wonogiri, which borders the Badegan District, Ponorogo District, East Java. The mob's rampage is said to have stemmed from the reckless actions of truck drivers who used to drive at night. There were no casualties in the incident but it resulted in the windows of two trucks breaking. Severe damage was experienced by the truck driven by Tohari, 35, a resident of Kepuh Gempol RT 001/RW 001, Padangan Village, Ngantru District, Tulungagung, East Java. Meanwhile, the truck with the number AG 8720 UY driven by Purwanto, 47 suffered damage to the headlights. Losses are estimated at IDR 42 million. Regarding the handling of this alleged vandalism case, the seven suspects were detained at the police station to avoid a more widespread incident. The seven suspects, respectively Sarno, Sutri WJ, Leri W, Rio P, Aiwika LK and Warno, are all residents of Badegan, Ponorogo, East Java and a resident of Purwantoro, Wonogiri, Wendi. ${ }^{15}$

At the level of settlement of the crime of vandalism, the Wonogiri Police as the investigator in the destruction which resulted in the damage to the victim's truck has attempted to mediate in handling the case. The Police have attempted to conduct penal mediation by bringing together the perpetrator-victim and the family to make peace with the terms as agreed by the parties. In the context of investigations with restorative justice, the police are the gatekeepers of the criminal justice system. Regarding this matter, Donald Black stated that the role of investigator and criminal investigator in its development placed the police with most of the ordinary or common crimes. Most police work reactive rather than proactive,

The role of the police in the implementation of restorative justice in the Grobogan area in the case of Damage of Goods is also not effective, even though the implementation of the settlement of cases of destruction of goods through nonpenal channels is very effective and efficient in resolving criminal cases of destruction of goods which are not included in serious crimes. The effectiveness of this restorative justice path in Grobogan can be seen in the Windayatun case where the goods in the form of trucks were damaged by Jumadi in the Responsibility Harjo area, where the results of the mediation facilitated by the Grobogan Police succeeded in reconciling the two parties with an agreement that the destroyer is responsible for replacing the item that was damaged. However, not all people want to do that. In the same area there was also a case on February 12, 2021 between Aminah, the truck owner and Budiono, who was the perpetrator of the truck vandalism. Aminah did not want to mediate through the local police, but filed a lawsuit to the court Furthermore, IPTU Winarno as the Head of the Tanggungharjo Police said that during January and March 2021, there were 15 cases of vandalism, 4 of which were related to truck vandalism with the motive of selling truck spare

15https://www.solopos.com/perusakan-truk-jengkel-lihat-truk-ugal-ugalan-laku-perusakan-7warga-ponorogo-jatim-diamankan-454901, accessed on 17 April 2021. 
parts for the benefit of the perpetrators, 6 cases of motor vehicle destruction and 5 cases of vandalism of houses and shops. ${ }^{16}$ Based on the existing cases, it can be seen that the implementation of the settlement of cases of destruction of goods based on restorative justice has not been carried out by all communities.

\section{Closing}

Settlement of cases based on restorative justice carried out through legal remedies outside the court basically has advantages. The main advantage of resolving cases including criminal cases outside the court with alternative dispute resolution (ADR) is that decisions made by the parties themselves (win win solutions) reflect a sense of justice. However, this has not been effective in resolving cases of vandalism. This is shown by the data above which shows the lack of implementation of alternative dispute resolution in resolving criminal cases of vandalism in the community. So it is necessary to introduce an alternative dispute resolution system for the community so that the public will understand the advantages of alternative dispute resolution in criminal cases of destruction of goods.

\section{References}

\section{Journals}

[1] Annis Nurwianti, Gunarto, Sri Endah Wahyuningsih, "Implementasi Restoratif / Restorative Justice Dalam Penyelesaian Tindak Pidana Kecelakaan Lalu Lintas Yang Dilakukan Oleh Anak Di Polres Rembang", Jurnal Hukum Khaira Ummah Vol. 12. No. 4 December 2017

[2] Arif Septria Hendra Saputra, Gunarto, dan Lathifah Hanim, "Penerapan Restoratife Justice Sebagai Alternatif Penyelesaian Tindak Pidana Penganiayaan Di Satreskrim Polsek Lasem", Jurnal Daulat Hukum Vol. 1. No. 1 March 2018

[3] Ibnu Suka, Gunarto, dan Umar Ma'ruf, "Peran Dan Tanggung Jawab Polri Sebagai Penegak Hukum Dalam Melaksanaan Restorative Justice Untuk Keadilan Dan Kemanfaatan Masyarakat", Jurnal Hukum Khaira Ummah Vol. 13. No. 1 March 2018

[4] Iman Faturrahman dan Bambang Tri Bawono, "Application of Restorative Justice to Solution of Traffic Accidents", Jurnal Daulat Hukum Volume 4 Issue 1, March 2021

[5] M.Gargarin Friyandi dan Aryani Witasari, "Restorative Justice In Application For Crime Investigation Abuse In Polsek Middle Semarang”, Jurnal Daulat Hukum Volume 2 Issue 1, March 2019

[6] Malik AL-Ghazali, "Restorative Justice Approach on The Under Age (Minors) Violator of The Traffic Case Accident (Laka) That Lead to Death in Polres Majalengka", Jurnal Daulat Hukum Volume 1 Issue 3 September 2018

16 IPTU Winarno, Personal Interview with the Head of Police of Tanggungharjo, interview on 20 June 2021. 
[7] Oscar Stefanus Setjo dan Umar Ma'ruf, "Investigation of Children Which Conflicting With Law in Narcotics Criminal Acts In Law Area of the Semarang City Police Jurisdiction", Jurnal Daulat Hukum Volume 3 Issue 2, June 2020

[8] Ragil Tri Wibowo dan Akhmad Khisni, "Restorative Justice in Application for Crime Investigation on Property", Jurnal Daulat Hukum Volume 1 No. 2 June 2018

[9] Sarwadi dan Bambang Tri Bawono, "Restorative Justice Approach in Diversion System for Settlement of Criminal Cases for Children in Indonesia", Jurnal Daulat Hukum Volume 3 Issue 4, December 2020

\section{Books}

[1] Abdul Wahid dan Muhammad Irfan, 2001, Perlindungan Terhadap Korban Kekerasan Seksual, Refika Aditama, Bandung

[2] Sugiono, 2009, Metode Penelitian Kuantitatif, Kualitatif dan R\&D, Alfabeta, Bandung

[3] Warsito Hadi Utomo, 2005, Hukum Kepolisian di Indonesia, Prestasi Pustaka, Jakarta

\section{Interview}

[1] IPTU Winarno, Personal Interview with the Head of Police of Tanggungharjo, interview on 20 June 2021.

\section{Internet}

[1] https://badilum.mahkamahagung.go.id/index.php?option=com attachments \&task=download\&id=811, accessed on 17 April 2021.

[2] https://www.solopos.com/perusakan-truk-jengkel-lihat-truk-ugal-ugalanlaku-perusakan-7-warga-ponorogo-jatim-diamankan-454901, accessed on 17 April 2021. 